\title{
ANALISIS PERJANJIAN PERKAWINAN MENURUT UNDANG-UNDANG PERKAWINAN DI INDONESIA
}

\author{
${ }^{1}$ Faradilla Asyatama, ${ }^{2}$ Fully Handayani Ridwan \\ Program Studi Magister Kenotariatan, Fakultas Hukum, Universitas Indonesia, Depok, Jawa Barat. \\ Correspondent email : faradilla.asyatama@ui.ac.id
}

$\begin{array}{lll}\mid \underline{\text { Article History }} & : & \\ \mid \text { Submission } & : & \text { 14 Oktober 2021 } \\ \text { |Last Revissions } & : & \text { 5 Desember 2021 } \\ \text { |Accepted } & : & \text { 5 Desember 2021 } \\ \text { |Copyedits Approved } & : & \text { 20 Desember 2021 }\end{array}$

\begin{abstract}
The protection of individual rights in marital relations according to positive Indonesian Law can be enforced by making a Prenuptial Agreement. Article 147 of the Civil Code states that a prenuptial agreement must be made before the marriage and must be in the form of a notarial deed which can apply to third parties since it registrates at the local District Court Registrar's Office and has been recorded on Marriage Deed in the Civil Registry. In Indonesia, there has been unification in the field of Marriage Law, which has resulted in several changes to the provisions of prenuptial agreement. This study is aimed at obtaining answers to the following problems: (1) How is the binding force of the prenuptial agreement after the enactment of Law Number 16 of 2019? (2) What is the concept of making a prenuptial agreement after the decision of Constitutional Court Number 69/PUU-XIII/2015? Solving this problem is persued by empirical normative legal research methods using secondary data. The results of this study are: (1) A prenuptial agreement's strength of binding after the enactment of the Marriage Law is after it is registered and ratified by a Marriage Registrar, and the content of prenuptial agreement is broader, not only coveting wealth; (2) The prenuptial agreement after the decision of Constitutional Court Number 69/PUU-XIII/2015 can be made after the marriage.
\end{abstract}

Keywords: Marriage, Regulation, Prenuptial, Agreement. 


\section{A. PENDAHULUAN}

Perkembangan era milenial sekarang ini, semakin banyak masyarakat Indonesia yang sadar akan pentingnya hukum bagi perlindungan diri sendiri. Salah satu bentuk perlindungan diri ialah dengan melindungi hak-haknya dalam suatu hubungan perkawinan. Perlindungan hak-hak individu dalam hubungan perkawinan menurut hukum positif Indonesia dapat diberlakukan dengan membuat suatu perjanjian perkawinan. Perjanjian perkawinan di Indonesia mulai diperbolehkan dibuat sejak diberlakukannya Kitab Undang-Undang Hukum Perdata pada tanggal 1 Mei $1848 .{ }^{1}$

Perjanjian perkawinan dalam Bahasa Inggris disebut juga dengan Prenuptial Agreement. Pengertian perjanjian perkawinan sendiri tidak terdapat penjelasan dalam Undang-Undang Perkawinan, melainkan hanya disebutkan mengenai istilahnya saja dan diatur mengenai keabsahannya, saat berlakunya, serta dapat diubahnya perjanjian tersebut. Soetojo Prawirohamidjojo mengemukakan bahwa perjanjian perkawinan merupakan perjanjian atau persetujuan yang dibuat oleh calon suami isteri, sebelum atau pada saat perkawinan dilangsungkan untuk mengatur akibat-akibat perkawinan terhadap harta kekayaan. $^{2}$

Perjanjian perkawinan menurut asalnya adalah terjemahan dari kata "huwelijkesevoorwaarden" yang terdapat dalam Burgerlijk Wetboek (BW) yang istilah ini juga terdapat dalam Kitab Undang-Undang Hukum Perdata. Kata "huwlijk" menurut bahasa berarti perkawinan antara seorang laki-laki dan seorang perempuan dan "voorwaard" mempunyai arti syarat atau persetujuan. Pengertian perjanjian perkawinan yaitu persetujuan yang dibuat untuk/dalam suatu perkawinan antara seorang laki-laki dan seorang perempuan. ${ }^{3}$

Secara umum, perjanjian perkawinan berisi tentang pengaturan harta kekayaan calon suami istri. Tujuan perjanjian perkawinan adalah untuk mengatur akibat-akibat perkawinan yang menyangkut harta kekayaan. Beberapa manfaat dari dibuatnya perjanjian perkawinan, antara lain: ${ }^{4}$

1. memisahkan harta kekayaan suami dan istri sehingga tidak terjadi percampuran harta kekayaan, sehingga apabila suatu saat terjadi perceraian diantara keduanya, masingmasing harta tetap dalam penguasaan masing-masing dan meminimalisir adanya konflik harta gono-gini;

2. masalah hutang yang dibuat dalam perkawinan akan menjadi tanggung jawab masingmasing;

\footnotetext{
${ }^{1}$ Hanafi Arief, "Perjanjian dalam Perkawinan (Sebuah Telaah Terhadap Hukum Positif di Indonesia)", Jurnal $A l ' A d l$ Vol IX No.2, (Agustus 2017).

2 Soetojo Prawirohamidjojo, Pluralisme dalam Perundang-Undangan Perkawinan di Indonesia, (Surabaya: Airlangga University Press, 1986), hlm. 57.

${ }^{3}$ Martias Gelar Imam Radjo Mulono, Penjelasan Istilah-Istilah Hukum Belanda Indonesia, (Jakarta: Ghalia, 1982), hlm. 107.

${ }^{4}$ Soetojo Prawirohamidjoyo dan Marthalena Pohan, Hukum Orang dan Keluarga, (Surabaya: Airlangga University Press, 2000), hlm. 79.
} 
3. apabila salah satu dari suami atau istri hendak mengalihkan dan/atau menjual harta kekayaan serta hendak melakukan suatu tindakan hukum tentang harta kekayaannya tidak diperlukan adanya izin dari pasangan (istri/suami); dan

4. tidak perlu adanya izin terlebih dahulu dari pasangan mengenai fasilitas kredit yang suami/istri ajukan dalam hal menjaminkan aset yang terdaftar atas namanya.

Berdasarkan pengertian dan tujuan tersebut, dapat diketahui bahwa perjanjian perkawinan menjadi salah satu bentuk perlindungan terhadap harta kekayaan individu dalam suatu perkawinan karena harta kekayaan merupakan suatu akibat hukum dari hubungan perkawinan. Perkawinan yang sah menurut hukum akan menimbulkan akibat hukum sebagai berikut: ${ }^{5}$

1. timbulnya hubungan antara suami-istri;

2. timbulnya harta benda dalam perkawinan; dan

3. timbulnya hubungan antara orang tua dan anak.

Dalam kehidupan perkawinan, selain masalah hak dan kewajiban sebagai suami dan istri, masalah harta benda dan kekayaan seringkali menjadi faktor penyebab berbagai perselisihan atau ketegangan dalam suatu perkawinan, bahkan menghilangkan kerukunan antara suami dan istri dalam kehidupan berkeluarga. Maka dari itu, pembuatan perjanjian perkawinan dapat menghindari hal tersebut. Berdasarkan Pasal 119 Kitab Undang-Undang Hukum Perdata, sejak saat dilaksanakannya perkawinan, menurut hukum berlakulah persatuan harta bulat antara harta kekayaan suami dan istri sepanjang tidak ada ketentuan lain yang dibuat dalam perjanjian perkawinan. Persatuan harta bulat maksudnya adalah harta suami dan istri setelah menikah akan bersatu tanpa ada pemisahan harta, tidak termasuk harta yang diperoleh sebelum perkawinan (harta bawaan), harta yang diperoleh berdasarkan pewarisan, dan harta yang diperoleh berdasarkan pemberian (hibah). Persatuan harta bulat itulah yang disebut harta bersama. ${ }^{6}$ Ketentuan mengenai harta bersama diatur dalam Undang-Undang Nomor 1 Tahun 1974 dalam pasal 35 ayat (1) bahwa harta benda yang diperoleh selama perkawinan menjadi harta bersama. Pasal 35 ayat (2) Harta bawaan dari masing-masing suami dan isteri dan harta benda yang diperoleh masing-masing sebagai hadiah atau warisan, adalah di bawah penguasaan masing-masing sepanjang para pihak tidak menentukan lain. Oleh karena itu, pengaturan mengenai harta diatur secara jelas dalam undang-undang perkawinan maupun kitab undang-undang hukum perdata.

Pasal 139 Kitab Undang-Undang Hukum Perdata kemudian menentukan bahwa "Dengan mengadakan perjanjian perkawinan, kedua calon suami istri adalah berhak menyiapkan beberapa penyimpangan dari peraturan perundang-undangan sekitar persatuan harta kekayaan, asal perjanjian itu tidak menyalahi tata susila yang baik atau tata tertib umum dan asal diindahkan pula segala ketentuan hukum yang berlaku."7

\footnotetext{
5 Mulyadi, Hukum Perkawinan Indonesia, (Semarang: Badan Penerbit Universitas Diponegoro, Cetakan Pertama, 2008), hlm. 41.

${ }^{6}$ Kitab Undang-Undang Hukum Perdata [Burgerlijk Wetboek voor Indonesie]. Diterjemahkan oleh R. Subekti dan R. Tjitrosudibio. (Jakarta: Pradnya Paramita, 2008), ps. 119.

${ }^{7}$ Ibid, ps. 139.
} 
Perjanjian kawin yang berisi penyimpangan terhadap persatuan-persatuan bulat biasanya dibuat oleh calon suami-istri yang jumlah kekayaannya sangat tidak berimbang, misal calon suami yang dikategorikan sangat mampu, sedangkan calon istri sangat kekurangan, atau sebaliknya. ${ }^{8}$

Perjanjian perkawinan menurut ketentuan Pasal 147 Kitab Undang-Undang Hukum Perdata harus dibuat sebelum perkawinan berlangsung dan harus dibuat dalam bentuk akta Notaris. Setelah dibuatkan dan dikonstantir dalam suatu akta Notaris, perjanjian perkawinan ini dapat mulai berlaku pada saat perkawinan telah dilaksanakan di depan Pegawai Catatan Sipil dan mulai berlaku terhadap pihak ketiga sejak dilakukannya pendaftaran di Kepaniteraan Pengadilan Negeri setempat, dimana dilangsungkannya perkawinan dan telah dicatat dalam Akta Perkawinan pada Catatan Sipil. ${ }^{9}$ Menurut Pasal 152 Kitab Undang-Undang Hukum Perdata, apabila pendaftaran perjanjian perkawinan belum didaftarkan di Kepaniteraan Pengadilan Negeri dan belum dicatatkan pada Akta Perkawinan Catatan Sipil, maka pihak ketiga boleh menganggap perjanjian perkawinan yang dibuat diantara suami-istri tersebut tidak sah dan menganggap suami-istri tersebut melaksanakan perkawinan dengan persatuan bulat harta kekayaan perkawinan. ${ }^{10}$

Seiring berjalannya waktu dengan bertambahnya peraturan-peraturan sebagai hukum positif di Indonesia, pada tanggal 1 Oktober 1975 telah berlaku Undang-Undang Nomor 1 Tahun 1974 tentang Perkawinan yang mengatur hal-hal mengenai hubungan perkawinan di Indonesia. Perjanjian perkawinan dalam Undang-Undang Nomor 1 Tahun 1974 tentang Perkawinan diatur dalam Bab V Pasal 29 dan diatur pula dalam Peraturan Pemerintah Tahun Nomor 9 Tahun 1975 tentang Pelaksanaan Undang-Undang Nomor 1 Tahun 1974 tentang Perkawinan. Pelaksanaan pembuatan perjanjian perkawinan juga mengalami perubahan setelah dikeluarkannya Putusan Mahkamah Konstitusi Nomor 69/PUU-XIII/2015.

Berdasarkan pemaparan di atas, maka rumusan masalah dari penulisan ini ialah: Bagaimana kekuatan mengikat perjanjian perkawinan pasca berlakunya Undang-Undang Nomor 1 Tahun 1974 sebagaimana diubah dalam Undang-Undang Nomor 16 Tahun 2019 yang dikaitkan dengan pembuatan perjanjian perkawinan pasca putusan Mahkamah Konstitusi Nomor 69/PUU-XIII/2015.

\section{B. METODE PENELITIAN}

Jenis penilitian yang digunakan oleh penulis ialah penelitian yuridis normatif Penelitian yuridis normatif yaitu penelitian dengan melaksanakan penelusuran terhadap bahan pustaka sebagai sumber penelitiannya. Bahan-bahan pustaka yang akan digunakan berupa literatur dan perundang-undangan yang berhubungan dengan perjanjian

\footnotetext{
${ }^{8}$ Mochamad Djais, Hukum Harta Kekayaan dalam Perkawinan, (Semarang: Fakultas Hukum Universitas Diponegoro, 2008), hlm. 101.

${ }^{9}$ Ramadhan Wira Kusuma, Pembuatan Perjanjian Kawin Setelah Perkawinan dan Akibat Hukumnya Terhadap Pihak Ketiga, (Semarang: Tesis Magister Kenotariatan Universitas Diponegoro, 2010), hlm. 19.

${ }^{10}$ Kitab Undang-Undang Hukum Perdata, op.cit, ps. 152.
} 
perkawinan di Indonesia. ${ }^{11}$ Data dalam penelitian ini diperoleh dari studi kepustakaan sehingga dapat diidentifikasi bahwa data yang digunakan adalah data sekunder yang terdiri dari buku-buku, jurnal-jurnal, perundang-undangan, maupun tulisan-tulisan lain yang berkaitan dengan perjanjian perkawinan. Metode analisis data yang digunakan dalam penelitian ini menggunakan analisis kualitatif, yaitu dengan cara memperhatikan keterkaitan data dan permasalahan yang dibahas, dan keterkaitan data dengan data-data lainnya sehingga didapatkan kesimpulan. Metode yang digunakan ialah metode pendekatan undang-undang (statute approach) yang menempatkan hukum sebagai norma dan menitikberatkan pada hukum sebagai tata perundang-undangan yang berlaku di Indonesia dan analisa penelitian dititikberatkan pada peraturan perundang-undangan dan putusan yang menjadi dasar terhadap permasalahan. ${ }^{12}$

\section{HASIL DAN PEMBAHASAN}

\section{Kekuatan Mengikat Perjanjian Perkawinan Menurut Undang-Undang Perkawinan}

Hukum positif Indonesia yang mengatur mengenai perjanjian perkawinan diatur dalam Kitab Undang-Undang Hukum Perdata, Undang-Undang Nomor 1 Tahun 1974 jo. Peraturan Pemerintah Nomor 9 Tahun 1975 tentang Pelaksanaan Undang-Undang Nomor 1 Tahun 1974 tentang Perkawinan. Ketentuan perjanjian perkawinan menurut Kitab Undang-Undang Hukum Perdata dengan Undang-Undang Nomor 1 Tahun 1974 terdapat perbedaan dan berdasarkan asas hukum yaitu asas lex specialis derogate legi generalis yang merupakan asas penafsiran hukum bahwa hukum yang bersifat khusus mengesampingkan hukum yang bersifat umum, maka ketentuan yang terdapat dalam Undang-Undang Nomor 1 Tahun 1974 tentang Perkawinan dan peraturan pelaksanaannya lebih efektif dilaksanakan dengan tetap mengindahkan ketentuan perjanjian perkawinan yang terdapat dalam Kitab Undang-Undang Hukum Perdata.

Undang-Undang Nomor 1 Tahun 1974 tentang Perkawinan mulai berlaku pada tanggal 1 Oktober 1975. Sejak berlakunya Undang-Undang Nomor 1 Tahun 1974 tentang Perkawinan, sehingga di Indonesia telah terjadi unifikasi dalam bidang Hukum Perkawinan, kecuali sepanjang yang belum atau tidak diatur dalam undangundang tersebut, maka peraturan lama dapat dipergunakan. ${ }^{13}$ Setelah diberlakukannya perundang-undangan tersebut, peraturan mengenai perkawinan di Indonesia, khususnya dalam pembahasan ini ialah mengenai perjanjian perkawinan mulai berlaku menggunakan Undang-Undang Perkawinan tersebut. Problematika perkawinan yang semakin kompleks mengakibatkan perubahan terhadap Undang-Undang Nomor 1 Tahun 1974 tentang Perkawinan dengan perubahan melalui Undang-Undang Nomor 16 Tahun 2019.

\footnotetext{
11 Amiruddin and Zainal Asikin, Pengantar Metode Penelitian Hukum, Ed. Revisi (Depok: Rajawali Press, 2020). hlm. 118

${ }^{12}$ Ibid. hlm. 164

${ }^{13}$ K. Wantjik Saleh, Hukum Perkawinan Indonesia, (Jakarta: Ghalia Indonesia, 1982), hlm. 3.
} 
Berdasarkan aturan Pasal 119 sampai dengan Pasal 198 Kitab Undang-Undang Hukum Perdata, dapat disimpulkan bahwa terdapat 3 (tiga) jenis perkawinan perjanjian, antara lain:

1. Perjanjian perkawinan pisah harta bawaan masing-masing suami atau istri. Pemisahan harta ini dipisahkan terhadap harta bawaan dari masing-masing suami istri yang didapatkan sebelum adanya hubungan perkawinan. Maka secara langsung, harta bawaan seperti hibah, waris, dan lain sebagainya tetap dalam penguasaan masing-masing suami atau istri. Mengenai harta yang diperoleh setelah adanya hubungan perkawinan tetap menjadi harta bersama keduanya yang dimiliki bersama;

2. Perjanjian perkawinan pemisahan untung rugi. Pemisahan ini meliputi pemisahan apabila terdapat keuntungan setelah adanya hubungan perkawinan diantara suami atau istri, maka keuntungan tersebut akan dibagi sama rata terhadap keduanya. Sedangkan, apabila terdapat kerugian setelah adanya hubungan perkawinan, maka kerugian tersebut menjadi tanggung jawab masing-masing antara suami atau istri tersebut;

3. Perjanjian perkawinan pemisahan harta secara bulat atau sepenuhnya. Pemisahan harta ini artinya seluruh harta dalam perkawinan, baik harta yang sudah ada sebelum adanya hubungan perkawinan maupun harta yang timbul sepanjang adanya hubungan perkawinan tersebut menjadi hak dari masingmasing suami dan istri. Dengan dibuatnya perjanjian perkawinan pemisahan harta secara bulat ini, maka diantara keduanya dapat melakukan suatu perbuatan hukum sendiri dari hartanya tanpa diperlukan persetujuan dari suami/istri.

Pembuatan perjanjian perkawinan pada umumnya memang berdasarkan kehendak para pihak, akan tetapi Pasal 139 sampai Pasal 143 Kitab Undang-Undang Hukum Perdata mengatur ketentuan yang tidak boleh dicantumkan dalam perjanjian perkawinan, antara lain:

1. perjanjian perkawinan tidak boleh bertentangan dengan kesusilaan dan ketertiban umum;

2. perjanjain perkawinan tidak boleh mengganggu hak-hak yang dilimpahkan kepada suami dalam kedudukannya sebagai kepala rumah tangga;

3. perjanjian perkawinan tidak boleh mengganggu hak-hak yang telah diberikan undang-undang kepada suami atau istri atau pasangan hidup yang paling lama;

4. perjanjian perkawinan tidak boleh melepaskan kewajiban hukumnya mengenai harta warisan keturunannya dan tidak dapat mengatur harta warisan keturunannya;

5. perjanjian perkawinan tidak boleh menetapkan bahwa yang satu harus bertanggung jawab atas bagian yang lebih besar dari utang harta bersama daripada yang lain; 
6. para pihak tidak boleh memperjanjikan bahwa ikatan perkawinannya akan diatur oleh hukum asing serta adat istiadat yang dahulu pernah berlaku di Indonesia dan daerah-daerah jajahannya.

Perjanjian perkawinan dibuat dalam akta Notaris karena dibutuhkan akta otentik untuk memberikan kepastian pembuktian dari perjanjian tersebut. Akta otentik ialah akta yang harus dibuat dalam bentuk yang ditentukan undang-undang, dibuat di hadapan pejabat yang berwenang, dan harus dibuat di tempat pejabat itu berwenang. ${ }^{14}$ Sebagaimana disebutkan dalam Pasal 15 Undang-Undang Nomor 30 Tahun 2004 tentang Jabatan Notaris jo. Undang-Undang Nomor 2 Tahun 2014 tentang Perubahan Atas Undang-Undang Nomor 30 Tahun 2004 tentang Jabatan Notaris yang menyebutkan bahwa Notaris dalam menjalankan tugasnya berwenang untuk membuat akta otentik bagi para pihak yang berkehendak, baik itu akta perjanjian perkawinan, maupun akta-akta otentik lainnya. ${ }^{15}$

Peranan dari seorang Notaris dalam pembuatan perjanjian perkawinan sangat diperlukan karena didalamnya mengatur banyak hal, khususnya mengenai harta kekayaan. Wewenang seorang Notaris dalam pembuatan akta yang dibuatnya adalah sebatas isi perjanjian yang telah memenuhi syarat sahnya perjanjian berdasarkan Pasal 1320 Kitab Undang-Undang Hukum Perdata yang mana menyebutkan syarat sah perjanjian yaitu adanya kesepakatan dari para pihak, para pihak harus cakap dalam membuat suatu perjanjian, terdapat suatu hal tertentu, dan suatu sebab yang halal. Akta Notaris akan menjadi alat bukti yang memiliki kekuatan pembuktian sempurna dan tidak dapat disangkal apabila dikemudian hari terjadi hal-hal yang tidak diinginkan, misalnya dalam hal memutus perkara perceraian, harta kekayaan masingmasing pihak, maupun utang-piutang.

Setelah pembuatan perjanjian perkawinan oleh Notaris dalam bentuk Akta Perjanjian Perkawinan, salinan akta tersebut perlu dicatatkan dan disahkan oleh Pegawai Pencatat Perkawinan dan kekuatan mengikat perjanjian perkawinan tersebut akan mengikat setelah Pegawai Pencatat Perkawinan membuat catatan pinggir pada register akta dan kutipan akta perkawinan atau menerbitkan Surat Keterangan bagi perjanjian perkawinan yang dibuat di Indonesia dan pencatatan perkawinannya dilakukan di Negara lain. ${ }^{16}$

Undang-Undang Nomor 1 Tahun 1974 dalam pasal 29 disebutkan bahwa perjanjian perkawinan dibuat pada waktu atau sebelum perkawinan dilangsungkan atas persetujuan bersama kedua belah pihak mengadakan perjanjian tertulis yang disahkan oleh Pegawai Pencatat Perkawinan, setelah mana isinya berlaku juga terhadap pihak ketiga sepanjang pihak ketiga tersangkut. ${ }^{17}$ Berdasarkan bunyi pasal tersebut, Undang-

\footnotetext{
${ }^{14}$ Gusti Muhammad Faruq Abdul Hakim Sutikno, "Kekuatan Hukum Pencatatan Perjanjian Perkawinan Bagi Para Pihak", Jurnal Privat Law Vol. VI No. 2 (Juli-Desember 2018), hlm. 222.

15 Indonesia, Undang-Undang Jabatan Notaris, UU No. 30 Tahun 2004, LN No. 117 Tahun 2014, TLN No. 4432, Ps. 15

${ }^{16}$ Direktorat Jenderal Kependudukan dan Pencatatan Sipil. Surat Edaran Nomor 472.2/5876/Dukcapil tentang Pencatatan Pelaporan Perjanjian Perkawinan, 19 Mei 2017.

${ }^{17}$ Indonesia, Undang-Undang Perkawinan, UU No. 1 Tahun 1974, LN No.1 Tahun 1974, TLN No. 3019, Ps. 29.
} 
Undang Perkawinan menyatakan bahwa kekuatan mengikat suatu perjanjian perkawinan yakni setelah didaftarkan dan disahkan oleh Pegawai Pencatat Perkawinan. Dengan demikian, terdapat perbedaan antara Undang-Undang Perkawinan dengan Kitab Undang-Undang Hukum Perdata yang menurut ketentuan Pasal 152 Kitab Undang-Undang Hukum Perdata menyatakan bahwa kekuatan mengikat dari suatu perjanjian perkawinan yakni sebelum dibukukan dalam suatu register umum di kepaniteraan pada Pengadilan Negeri dimana dalam daerah hukumnya perkawinan tersebut dilangsungkan. Dari kedua ketentuan tersebut, yang berlaku pada saat ini berdasarkan asas lex specialis derogate legi generalis, maka ketentuan dalam Kitab Undang-Undang Hukum Perdata mengenai kekuatan mengikat perjanjian perkawinan dikesampingkan oleh Undang-Undang Perkawinan, serta asas lex posterior derogate legi priori, yaitu asas penafsiran hukum bahwa hukum terbaru mengesampingkan hukum yang lama, maka ketentuannya berlaku ketentuan yang terbaru.

Perjanjian perkawinan termasuk peristiwa yang penting berdasarkan klausulaklausula yang terdapat dalam perjanjian perkawinan yang dibuat berdasarkan kehendak kedua belah pihak, sehingga perjanjian perkawinan perlu didaftarkan dan dicatatkan dalam rangka mencatat peristiwa-peristiwa penting dalam kehidupan manusia. Ketentuan tentang keabsahan perjanjian perkawinan baru mengikat setelah didaftarkan dan dicatatkan oleh Pegawai Pencatat Perkawinan menjadikan pihak ketiga harus benar-benar mengetahui bahwa perjanjian perkawinan tersebut telah didaftarkan atau hanya sekedar membuat perjanjian perkawinan saja. Pihak ketiga dapat mengangap perkawinan berlangsung dengan harta persatuan apabila para pihak tindak mendaftarkan dan dicatatkan oleh Pegawai Pencatat Perkawinan. Sehingga, apabila terjadi persangkutang hutang dengan suami atau istri, penyelesaiannya dilakukan dengan melibatkan harta bersama. Perjanjian perkawinan yang tidak didaftarkan dan tidak dicatatkan oleh Pegawai Pencatat Perkawinan hanya berlaku antara kedua pihak saja.

Undang-Undang Perkawinan dalam menentukan isi dalam perjanjian perkawinan tidak menekankan pada harta kekayaan saja, sesuai dengan Pasal 29 ayat (2) Undang-Undang Perkawinan yang menyatakan bahwa Perjanjian tersebut tidak dapat disahkan bilamana melanggar batas-batas hukum, agama, dan kesusilaan. Apabila dibandingkan dengan ketentuan Kitab Undang-Undang Hukum Perdata mengenai perjanjian perkawinan, isi perjanjiannya hanya menekankan pada harta kekayaan suami istri saja.

Perjanjian perkawinan lazimnya dibuat hanya untuk mengatur harta kekayaan dalam hubungan perkawinan. Akan tetapi, apabila mengacu pada asas kebebasan berkontrak sebagaimana diatur dalam Pasal 1338 Kitab Undang-Undang Hukum Perdata, maka dapat disimpulkan bahwa perjanjian perkawinan dapat ditambahkan klausula-klausula tambahan mengenai apa yang ingin diatur dalam perjanjian perkawinan tersebut asalkan tidak melanggar batas-batas hukum, agama, dan 
kesusilaan, serta ketentuan yang terdapat dalam Pasal 140, 141, 142, dan 143 Kitab Undang-Undang Hukum Perdata yang melarang untuk mengurangi atau menghilangkan hak-hak masing-masing suami istri. Beberapa contoh perjanjian perkawinan diluar harta kekayaan yaitu kejahatan rumah tangga, memperjanjikan salah satu pihak untuk tetap berkarir meski sudah menikah, dan lain sebagainya. ${ }^{18}$

\section{Konsep Pembuatan Perjanjian Perkawinan Pasca Putusan Mahkamah Konstitusi Nomor 69/PUU-XIII/2015}

Keberadaan Mahkamah Konstitusi sebagai guardian of constitution semenjak diamandemennya Undang-Undang Dasar Negara Republik Indonesia Tahun 1945 telah banyak melahirkan putusan-putusan yang menarik perhatian masyarakat. ${ }^{19}$ Mahkamah Konstitusi merupakan suatu lembaga negara di bidang kekuasaan kehakiman yang berwenang mengadili pada tingkat pertama dan terakhir yang mana putusannya bersifat final untuk menguji undang-undang terhadap Undang-Undang Dasar Negara Republik Indonesia Tahun 1945.

Kekuatan hukum dari putusan Mahkamah Konstitusi terdiri dari kekuatan hukum mengikat, kekuatan hukum pembuktian, dan kekuatan hukum eksekutorial. ${ }^{20}$ Kekuatan hukum mengikat daripada putusan Mahkamah Konstitusi tidak hanya mengikat bagi para pihak yang berperkara, melainkan mengikat dan/atau ditujukan kepada semua warga negara, lembaga/pejabat negara dan badan hukum dalam wilayah Republik Indonesia.

Salah satu putusan Mahkamah Konstitusi yang putusannya mengenai perjanjian perkawinan pada tahun 2016 telah menjadi ketentuan baru bagi perjanjian perkawinan sebagai tindak lanjut dari Putusan Mahkamah Konstitusi Republik Indonesia Nomor 69/PUU-XIII/2015 tanggal 27 Oktober 2016. Latar belakang dari dikeluarkannya Putusan ini ialah karena adanya rasa diskriminasi dan dilanggarnya hak konstitusional dari Pemohon yang telah menikah dengan Warga Negara Asing tanpa adanya perjanjian perkawinan terlebih dahulu sebelum perkawinan berlangsung, sehingga mengakibatkan terjadinya persatuan harta dan hak Pemohon untuk memiliki Hak Milik dan Hak Guna Bangunan atas tanah menjadi hilang dan terampas selamanya. Sehingga Pemohon sebagai warga negara Indonesia tidak akan pernah berhak untuk mempunyai Hak Milik dan Hak Guna Bangunan seumur hidupnya.

Akibat hukum adanya hubungan perkawinan antara Warga Negara Indonesia dengan Warga Negara Asing berdampak pada status kewarganegaraan dan kepemilikan aset. Hal ini dapat dilihat dalam ketentuan Pasal 21 ayat (3) UndangUndang Nomor 5 Tahun 1960 tentang Peraturan Dasar Pokok-Pokok Agraria yang

\footnotetext{
${ }^{18}$ Muchsin, Perjanjian Perkawinan dalam Perspektif Hukum Nasional, (Jakarta: Varia Peradilan, 2008), hlm. 7.

${ }^{19}$ Si Ngurah Ardhya dan I Putu Windu Mertha Sujana, "Konsekuensi Yuridis Berlakunya Perjanjian Perkawinan Pasca Putusan Mahkamah Konstitusi Nomor 69/PUU-XIII/2015”, Jurnal Komunikasi Hukum Vol. 7 No. 1 (Februari 2021), hlm. 297.

${ }^{20}$ Eva Dwinopanti, "Implikasi dan Akibat Hukum Putusan Mahkamah Konstitusi Nomor 69/PUU-XIII/2015 terhadap Pembuatan Akta Perjanjian Perkawinan Setelah Kawin yang Dibuat di Hadapan Notaris", Lex Renaissance Vol.2 No.1 (Januari 2017), hlm. 25.
} 
menyatakan bahwa Warga Negara Indonesia yang mempunyai hak milik dan setelah berlakunya undang-undang ini kehilangan kewarganegaraannya wajib melepaskan hak milik dalam jangka waktu satu tahun sejak hilangnya kewarganegaraan itu. ${ }^{21}$ Oleh karena itu, Pemohon mengajukan permohonan pengujian materiil terhadap Pasal 21 ayat (1), ayat (3), dan Pasal 36 ayat (1) Undang-Undang Peraturan Dasar PokokPokok Agraria, serta Pasal 29 ayat (1), ayat (3), ayat (4), dan Pasal 35 ayat (1) Undang-Undang Perkawinan yang mengakibatkan terampasnya hak-hak asasi Pemohon sebagai seorang Warga Negara Indonesia yang menikah dengan Warga Negara Asing. Mahkamah Konstitusi menimbang dan mengabulkan permohonan Pemohon untuk sebagian.

Terlepas dari permohonan Pemohon, hak lain yang dapat hilang akibat tidak diadakannya perjanjian perkawinan antara Warga Negara Indonesia yang menikah dengan Warga Negara Asing ialah haknya atas harta benda dan saham dalam Perseroan Terbatas (PT) Indonesia. Dalam PT Penanaman Modal Dalam Negeri, perseorangan atau badan usaha yang melakukan penanaman modal dalam negeri harus perseorangan Warga Negara Indonesia. ${ }^{22}$ Apabila terdapat unsur penanam modal Warga Negara Asing, maka status perseroan harus dialihkan menjadi PT Penanaman Modal Asing (PT PMA).

Putusan Mahkamah Konstitusi Nomor 69/PUU-XIII/2015 dikeluarkan dengan tujuan mengatur tentang waktu pembuatan perjanjian perkawinan. Kitab UndangUndang Hukum Perdata dan Undang-Undang Perkawinan hanya mengatur mengenai pembuatan perjanjian pada waktu atau sebelum perkawinan dilangsungkan, sedangkan ketentuan tersebut diubah dan disempurnakan setelah dikeluarkannya Putusan Mahkamah Konstitusi Republik Indonesia Nomor 69/PUU-XIII/2015 yang menyatakan bahwa pemaknaan dari Pasal 29 ayat (1) Undang-Undang Perkawinan yaitu pada waktu, sebelum dilangsungkan atau selama dalam ikatan perkawinan kedua belah pihak atas persetujuan bersama dapat mengajukan perjanjian tertulis yang disahkan oleh pagawai pencatat perkawinan atau notaris, setelah mana isinya berlaku juga terhadap pihak ketiga sepanjang pihak ketiga tersangkut. Pasal 29 ayat (4) menyatakan selama perkawinan berlangsung, perjanjian kawin dapat mengenai harta perkawinan atau perjanjian lainnya, tidak dapat diubah atau dicabut, kecuali dari kedua belah pihak ada persetujuan untuk mengubah atau mencabut, dan perubahan atau pencabutan itu tidak merugikan pihak ketiga. ${ }^{23}$

Pada intinya, Putusan Mahkamah Konstitusi Republik Indonesia Nomor 69/PUU-XIII/2015 mengubah konsep perjanjian perkawinan yang semula hanya dibuat pada waktu atau sebelum berlangsungnya perkawinan menjadi perjanjian perkawinan dapat juga dibuat pada saat dan selama perkawinan berlangsung. Dengan

\footnotetext{
${ }^{21}$ Indonesia, Undang-Undang Peraturan Dasar Pokok-Pokok Agraria, UU No. 5 Tahun 1960, LN No.104 Tahun 1960, TLN No. 2043, Ps. 21.

${ }^{22}$ Indonesia, Undang-Undang Penanaman Modal, UU No. 25 Tahun 2007, LN No. 67 Tahun 2007, TLN No. 4724, ps. 1 butir 5 .

${ }^{23}$ Mahkamah Konstitusi Republik Indonesia, Putusan Nomor 69/PUU-XIII/2015.
} 
dikeluarkannya Putusan Mahkamah Konstitusi Republik Indonesia Nomor 69/PUUXIII/2015 memberikan kelonggaran dalam ketentuan perjanjian perkawinan yang sangat menguntungkan Warga Negara Indonesia yang telah terlanjur melangsungkan perkawinan dengan Warga Negara Asing, khususnya bagi para pihak yang sebelum perkawinan berlangsung tidak membuat suatu perjanjian perkawinan pisah harta yang mana Warga Negara Indonesia tersebut akan kehilangan hak untuk memiliki bangunan dan tanah di wilayah Indoenesia.

Putusan Mahkamah Konstitusi dalam hal ini tidak hanya mengatur mengenai akibat hukum perjanjian perkawinan setelah perkawinan berlangsung terhadap status harta kedua belah pihak, melainkan juga mengatur secara implisit akibat hukum terhadap pihak ketiga. Adanya ketentuan dapat dibuatnya suatu perjanjian perkawinan setelah perkawinan berlangsung memunculkan kekhawatiran akan timbulnya kerugian bagi pihak ketiga. Oleh karena itu, solusi untuk menghindari kerugian pihak ketiga ialah Notaris dalam hal diminta membuat akta perjanjian perkawinan setelah berlangsungnya perkawinan, meminta terlebih dahulu kepada para pihak untuk dapat melakukan pengumuman pada surat kabar yang terbit di kota domisili para pihak dan/atau tempat perkawinan para pihak dilangsungkan mengenai akan dibuatnya suatu perjanjian perkawinan di antara para pihak. Pengumuman surat kabar ini dimaksudkan untuk memberi kesempatan kepada pihak lain yang merasa keberatan akan akibat dari setelah dibuatnya perjanjian perkawinan para pihak karena dibuat setelah perkawinan berlangsung.

Selain itu, mengingat bahwa suatu perjanjian perkawinan baru dikatakan sah dan mengikat pada pihak ketiga setelah perjanjian perkawinan tersebut didaftarkan dan dicatatkan pada Kantor Catatan Sipil atau Kantor Urusan Agama. Pendaftaran dan pencatatan perjanjian perkawinan meskipun perjanjian perkawinan dibuat setelah berlangsungnya perkawinan tetap harus dilakukan. Pencatatan dan pendaftaran tersebut harus didahului dengan pengajuan permohonan ke pengadilan agar pengadilan memberikan perintah kepada Kantor Catatan Sipil atau Kantor Urusan Agama untuk mendaftarkan dan mencatatkannya. Setelah dicatatkan dan didaftarkan, barulah sah perjanjian perkawinan tersebut dan memberi kepastian hukum bagi pihak ketiga.

\section{KESIMPULAN}

Berdasarkan uraian permasalahan dan pembahasan di atas, maka Penulis dapat menyimpulkan sebagai berikut:

1. Hukum positif Indoensia mengenai perjanjian perkawinan pasca berlakunya Undang-Undang Nomor 1 Tahun 1974 sebagaimana diubah dalam UndangUndang Nomor 16 tahun 2019 tentang Perkawinan, kekuatan perjanjian perkawinan yang semula diatur dalam Kitab Undang-Undang Hukum Perdata kekuatan mengikatnya setelah didaftarkan di kepaniteraan pada Pengadilan Negeri dimana perkawinan dilangsungkan, akan tetapi Undang-Undang Perkawinan mengatur ketentuan baru yaitu kekuatan mengikatnya berlaku sejak dicatatkan dan disahkan oleh Pegawai Pencatat Perkawinan. Dapat disimpulkan bahwa pencatatan tidak lagi dilakukan pada Pengadilan Negeri, melainkan dicatat dan 
disahkan oleh Pegawai Pencatat Perkawinan. Ketentuan mengenai isi dari perjanjian perkawinan lebih luas dibandingkan dengan ketentuan Kitab UndangUndang Hukum Perdata yang hanya berisi harta kekayaan dalam hubungan perkawinan. Ketentuan lain yang disepakati dalam perjanjian perkawinan selain harta kekayaan tidak boleh melanggar batas-batas hukum, agama, dan kesusilaan, serta tidak mengurangi atau menghilangkan hak-hak masing-masing suami istri.

2. Hukum positif Indonesia mengenai perjanjian perkawinan pasca berlakunya Putusan Mahkamah Konstitusi Republik Indonesia Nomor 69/PUU-XIII/2015 ketentuan mengenai pembuatan perjanjian perkawinan dapat dibuat pada waktu perkawinan, sebelum dilangsungkan perkawinan, atau selama perkawinan berlangsung. Perjanjian perkawinan yang dibuat setelah perkawinan berlangsung harus didahului dengan pengumuman melalui surat kabar agar tidak menimbulkan kerugian setelah mengikat pihak ketiga.

Adapun rekomendasi dari hasil penelitian ini adalah sebagai berikut:

1. Diharapkan bagi masyarakat Indonesia untuk lebih memperhatikan hak-hak masing-masing, terlebih dalam suatu hubungan perkawinan yang akan melibatkan harta kekayaan dari kedua belah pihak dengan membuat suatu perjanjian perkawinan yang kemudian didaftarkan pada Pegawai Pencatat Nikah. Bagi warga negara yang beragama Islam, mendaftarkan dan mencatatkan perjanjian perkawinannya pada Kantor Urusan Agama. Sedangkan, warga negara yang beragama selain Islam mendaftarkan dan mencatatkan perjanjian perkawinannya pada Kantor Pencatatan Sipil.

2. Bagi Warga Negara Indonesia yang hendak melaksanakan perkawinan dengan Warga Negara Asing agar tetap mendapatkan haknya dalam kepemilikan aset di Indonesia, sangat disarankan untuk membuat perjanjian perkawinan pisah harta pada saat perkawinan, sebelum berlangsungnya perkawinan, atau setelah berlangsungnya perkawinan. Apabila telah terlanjur melaksanakan perkawinan, maka perjanjian perkawinan dapat dibuat setelah perkawinan dan didahului dengan adanya pengumuman melalui surat kabar guna memberikan kesempatan bagi pihak ketiga yang merasa keberatan dengan akibat hukum dari dibuatnya perjanjian perkawinan tersebut.

\section{DAFTAR PUSTAKA}

\section{Buku :}

Amiruddin and Zainal Asikin, Pengantar Metode Penelitian Hukum, Ed. Revisi (Depok: Rajawali Press, 2020)

Djais, Mochamad. Hukum Harta Kekayaan dalam Perkawinan. Semarang: Fakultas Hukum Universitas Diponegoro, 2008.

Muchsin. Perjanjian Perkawinan dalam Perspektif Hukum Nasional. Jakarta: Varia Peradilan, 2008.

Mulono, Martias Gelar Imam Radjo. Penjelasan Istilah-Istilah Hukum Belanda Indonesia. Jakarta: Ghalia, 1982.

Mulyadi. Hukum Perkawinan Indonesia. Cetakan Pertama. Semarang: Badan Penerbit Universitas Diponegoro, 2008. 
AJUDIKASI : Jurnal Ilmu Hukum, Volume 5 Nomor 2, Desember 2021. Hlm. 109-122 P-ISSN 2613-9995 \& E-ISSN 2614-0179

Prawirohamidjojo, Soetojo. Pluralisme dalam Perundang-Undangan Perkawinan di Indonesia. Surabaya: Airlangga University Press, 1986.

dan Marthalena Pohan. Hukum Orang dan Keluarga. Surabaya: Airlangga University Press, 2000.

Saleh, K. Wantjik. Hukum Perkawinan Indonesia. Jakarta: Ghalia Indonesia, 1982.

\section{Jurnal}

Ardhya, Si Ngurah dan I Putu Windu Mertha Sujana. "Konsekuensi Yuridis Berlakunya Perjanjian Perkawinan Pasca Putusan Mahkamah Konstitusi Nomor 69/PUUXIII/2015". Jurnal Komunikasi Hukum Vol. 7 No. 1 (Februari 2021).

Arief, Hanafi. "Perjanjian dalam Perkawinan (Sebuah Telaah Terhadap Hukum Positif di Indonesia)". Jurnal Al'Adl Vol IX No.2 (Agustus 2017).

Dwinopanti, Eva. "Implikasi dan Akibat Hukum Putusan Mahkamah Konstitusi Nomor 69/PUU-XIII/2015 terhadap Pembuatan Akta Perjanjian Perkawinan Setelah Kawin yang Dibuat di Hadapan Notaris”. Lex Renaissance Vol.2 No.1 (Januari 2017).

Sutikno, Gusti Muhammad Faruq Abdul Hakim. "Kekuatan Hukum Pencatatan Perjanjian Perkawinan Bagi Para Pihak”. Jurnal Privat Law Vol. VI No. 2 (Desember 2018).

\section{Thesis}

Kusuma, Ramadhan Wira. Pembuatan Perjanjian Kawin Setelah Perkawinan dan Akibat Hukumnya Terhadap Pihak Ketiga. Semarang: Tesis Magister Kenotariatan Universitas Diponegoro, 2010.

\section{Peraturan Perundang-Undangan}

Kitab Undang-Undang Hukum Perdata [Burgerlijk Wetboek voor Indonesie]. Diterjemahkan oleh R. Subekti dan R. Tjitrosudibio. Jakarta: Pradnya Paramita, 2008.

Indonesia. Undang-Undang Peraturan Dasar Pokok-Pokok Agraria. UU Nomor 5 Tahun 1960. Lembar Negara Nomor 104 Tahun 1960. Tambahan Lembar Negara Nomor 2043.

Indonesia. Undang-Undang Perkawinan, UU Nomor 1 Tahun 1974. Lembar Negara Nomor 1 Tahun 1974. Tambahan Lembar Negara Nomor 3019.

Indonesia. Undang-Undang Jabatan Notaris. UU Nomor 30 Tahun 2004. LN No. 117 Tahun 2004. TLN No. 4432.

Indonesia. Undang-Undang Penanaman Modal. UU No. 25 Tahun 2007. LN No. 67 Tahun 2007. TLN No. 4724

Indonesia. Undang-Undang Perubahan atas Undang-Undang Nomor 30 Tahun 2004 tentang Jabatan Notaris. UU Nomor 2 Tahun 2014. LN No. 3 Tahun 2014. TLN No. 5491.

Peraturan Pemerintah Nomor 9 Tahun 1975 tentang Pelaksanaan Undang-Undang Nomor 1 Tahun 1974 tentang Perkawinan. LN No. 12 Tahun 1975. TLN No. 3050.

Putusan Mahkamah Konstitusi Republik Indonesia. Putusan Nomor 69/PUU-XIII/2015. 
AJUDIKASI : Jurnal Ilmu Hukum, Volume 5 Nomor 2, Desember 2021. Hlm. 109-122 P-ISSN 2613-9995 \& E-ISSN 2614-0179

\section{Surat Edaran}

Direktorat Jenderal Kependudukan dan Pencatatan Sipil. Surat Edaran Nomor 472.2/5876/Dukcapil tentang Pencatatan Pelaporan Perjanjian Perkawinan. 19 Mei 2017 